\title{
Good Corporate Governance Memoderasi Pengaruh Earnings Management dan Likuiditas pada Kualitas Laba
}

\author{
I Ketut Mandi Wira Putra ${ }^{1}$ \\ Fakultas Ekonomi dan Bisnis \\ Universitas Udayana, Indonesia
}

\author{
Anak Agung Gde Putu Widanaputra2 \\ Fakultas Ekonomi dan Bisnis \\ Universitas Udayana, Indonesia
}

Surel : putra.wira1607531081@gmail.com

\begin{abstract}
ABSTRAK
Penelitian ini bertujuan untuk memperoleh bukti empiris pengaruh earnings management dan likuiditas pada kualitas laba dengan good corporate governance sebagai variabel moderasi, di perusahaan yang masuk dalam pemeringkatan Corporate Governance Perception Index (CGPI). Penelitian ini menggunakan metode asosiatif dengan data yang dikumpulkan berdasarkan observasi non partisipan. Sampel ditentukan menggunakan teknik purposive sampling, sehingga diperoleh 35 amatan selama periode penelitian. Teknik analisis data yang digunakan yaitu teknik Moderated Regression Analysis (MRA). Hasil penelitian menunjukkan bahwa good corporate governance memoderasi yang melemahkan hubungan antara earnings management dengan kualitas laba. Selain itu, penelitian ini menghasilkan bahwa good corporate governance tidak berpengaruh terhadap hubungan likuiditas dengan kualitas laba.
\end{abstract}

Kata Kunci: Earnings Management; Likuiditas; Kualitas Laba; Good Corporate Governance.

\section{Good Corporate Governance Moderates the Effect of Earnings Management and Liquidity on Earnings Quality}

\section{ABSTRACT}

The purpose of this study is to obtain empirical evidence on the effect of earnings management and liquidity on earnings quality, with good corporate governance serving as a moderating variable, in companies ranked by the Corporate Governance Perception Index (CGPI). This study employs the associative method, with data gathered from nonparticipant observations. Purposive sampling was used to determine the sample, and 35 firm-year were obtained during the study period. The Moderated Regression Analysis (MRA) technique was used for data analysis. According to the findings, good corporate governance modifies the relationship between earnings management and earnings quality. Furthermore, according to the findings of this study, good corporate governance has no effect on the relationship between liquidity and earnings quality.

Keywords: $\quad$ Earnings Management; Liquidity; Earnings Quality; Good Corporate Governance.

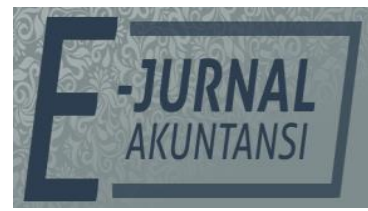

e-ISSN 2302-8556

Vol. 31 No. 8

Denpasar, Agustus 2021 Hal. 2041-2057

DOI:

10.24843/EJA.2021.v31.i08.p13

PENGUTIPAN:

Putra, I K.M.W., \&

Widanaputra, A.A.G.P.

(2021). Good Corporate

Governance Memoderasi

Pengaruh Earnings Management dan Likuiditas pada Kualitas Laba. E-Jurnal Akuntansi, 31(8), 2041-2057

RIWAYAT ARTIKEL:

Artikel Masuk:

31 Mei 2021

Artikel Diterima: 26 Agustus 2021

Artikel dapat diakses : https://ojs.unud.ac.id/index.php/Akuntansi/index 


\section{PENDAHULUAN}

Laba merupakan informasi yang ditunggu-tunggu oleh investor dan dapat mempengaruhi investor dalam membuat keputusan investasi pada suatu perusahaan. Laba yang dihasilkan oleh perusahaan, baik itu bersifat positif maupun negative akan memberikan dampak atau pengaruh terhadap reaksi pasar dan pergerakan harga saham. Informasi laba merupakan perhatian utama dalam mengukur keberhasilan atau kegagalan suatu bisnis dalam mencapai tujuan operasional yang telah ditentukan (Sadalia et al., 2017). Fauzi (2015), mengatakan bahwa informasi laba biasanya digunakan oleh pihak eksternal sebagai indicator untuk mengukur kinerja operasional perusahaan. Dalam perspektif tujuan kontrak, informasi laba dapat digunakan untuk membuat keputusan yang berkaitan dengan praktik corporate governance, juga dapat digunakan sebagai dasar untuk alokasi gaji dalam suatu perusahaan. Dalam perspektif pengambilan keputusan investasi, informasi laba penting bagi investor untuk mengetahui kualitas laba sebagai informasi. Oleh karena itu kualitas laba menjadi perhatian bagi investor dan para pengambil kebijakan akuntansi serta pemerintahan.

Kualitas informasi keuangan yang telah disajikan sering diasosiasikan sebagai kualitas laba. Terdapat berbagai pengertian mengenai kualitas laba dalam perspektif kebermanfaatan di dalam pengambilan keputusan (decision usefulness). Schipper \& Vincent (2003) mengelompokkan konstruk kualitas laba dan pengukurannya berdasarkan cara menentukan kualitas laba, yaitu Berdasarkan sifat runtun-waktu laba, kualitas laba meliputi persistensi, prediktabilitas (kemampuan prediksi), dan variabilitas. Kualitas laba didasarkan pada hubungan laba-kas-akrual yang dapat diukur dengan berbagai ukuran, yaitu rasio kas operasi dengan laba, perubahan akrual total, estimasi abnormal, discretionary accruals (akrual abnormal atau DA), dan estimasi hubungan akrual-kas. Memaksimalkan kualitas laba sangat penting dalam dunia bisnis hal ini karena laba yang diperoleh merupakan sesuatu yang sangat penting dalam suatu perusahaan. Schipper \& Vincent (2003) mengatakan bahwa kualitas laba khususnya dan kualitas laporan keuangan pada umumnya adalah penting bagi mereka yang menggunakan laporan keuangan untuk tujuan kontrak dan pengambilan keputusan investasi.

Manajer sebagai pihak internal perusahaan lebih banyak memiliki informasi mengenai kondisi perusahaan di bandingkan pihak eksternal. Hal ini yang menyebabkan adanya tindakan manajemen perusahaan untuk melaporkan laba yang tidak menggambarkan kondisi perusahaan yang sebenarnya untuk kepentingan pribadi. Adanya tindakan manajemen yang melaporkan laba yang tidak menggambarkan kondisi perusahaan yang sebenarnya mengakibatkan laba yang dihasilkan menjadi diragukan kualitasnya. Fenomena ini dapat merugikan banyak pihak pengguna laporan keuangan dimana masing-masing pihak mempunyai kepentingan tersendiri atas informasi dari laporan keuangan tersebut (Fama \& Jensen, 1983) dan (Jensen \& Meckling, 1976).

Saat ini laporan keuangan telah menjadi isu sentral sebagai sumber penyalahgunaan informasi yang merugikan pihak-pihak yang berkepentingan. Tercatat telah terjadi banyak skandal keuangan di perusahaan-perusahaan publik dengan melibatkan persoalan laporan keuangan yang pernah diterbitkannya. Skandal pelaporan keuangan sudah banyak terjadi, di luar negeri terdapat kasus 
skandal pelaporan akuntansi dengan melakukan manajemen laba, antara lain Enron, Merck, World Com dan mayoritas perusahaan lain di Amerika Serikat (Cornett et al., 2006). Beberapa kasus yang terjadi di Indonesia, seperti yang dilakukan oleh PT Kimia Farma Tbk. PT Kimia Farma diduga melakukan markup laba bersih pada tahun 2001 dalam laporan keuangannya. Kimia Farma menyebutkan berhasil memperoleh laba sebesar Rp 132 miliar. Setelah dilakukan audit ulang, pada 3 Oktober 2002 laporan keuangan Kimia Farma 2001 disajikan kembali (restated), karena telah ditemukan kesalahan yang cukup mendasar. Pada laporan keuangan yang baru, keuntungan yang disajikan hanya sebesar Rp 99,56 miliar, atau lebih rendah sebesar Rp 32,6 miliar, atau 24,7 persen dari laba awal yang dilaporkan (http://davidparsaoran.wordpress.com, 2009). Selain itu kasus PT. Katarina Utama Tbk diduga telah memanipulasi laporan keuangan sebagaimana dituduhkan oleh salah satu pemegang sahamnya yakni PT. Media Intertel Graha (MIG) laporan keuangan 2009 yang mencantumkan pendapatan dari MIG Rp 6.773 miliar dan adanya piutang usaha dari MIG sebesar Rp 8.606 miliar (finance.detik.com, 2010). Sementara itu, salah satu kasus terbaru yang juga terjadi di Indonesia yaitu PT Garuda Indonesia Tbk (GIAA) disebut telah mempercantik laporan keuangannya pada tahun 2018. Laporan Keuangan GIAA dikatakan janggal karena laba yang diperoleh pada tahun 2018 cukup signifikan. Menurut Laporan Keuangan GIAA pada tahun 2018, perusahaan mencatat laba bersih sebesar US\$ 809,85 ribu atau setara Rp 11,33 miliar (kurs Rp 14.000). Padahal di kuartal III-2018 GIAA masih mengalami kerugian sebesar US\$ 114,08 juta atau Rp 1,66 triliun. Hal tersebut tentu akan merugikan pihak-pihak yang menjalin kerjasama dengan perusahaan tersebut karena telah menyajikan laporan keuangan yang berbeda dengan keadaan perusahaan yang sebenarnya. Sehingga Garuda Indonesia harus menyajikan ulang laporan keuangannya (restatement) untuk tahun 2018 (finance.detik.com, 2019).

Fenomena ini menunjukkan terjadinya skandal keuangan merupakan kegagalan laporan keuangan untuk memenuhi kebutuhan informasi para pengguna laporan. Laba sebagai bagian dari laporan keuangan tidak menyajikan fakta yang sebenarnya tentang kondisi ekonomis perusahaan sehingga laba yang diharapkan dapat memberikan informasi untuk mendukung pengambilan keputusan menjadi diragukan kualitasnya. Laba yang tidak menunjukkan informasi yang sebenarnya tentang kinerja manajemen dapat berdampak pada tidak maksimalnya tujuan yang dicapai pihak pengguna laporan.

Secara teoritis, kualitas laba dapat dipengaruhi oleh tindakan manajemen laba dan likuiditas perusahaan. Hal ini dapat dijelaskan dengan teori keagenan. Menurut teori keagenan, adanya pemisahan antara kepemilikan dan pengelolaan perusahaan dapat menimbulkan konflik. Terjadi konflik yang disebut konflik keagenan disebabkan pihak-pihak yang terkait yaitu prinsipal (pemegang saham) dan agen (manajemen) mempunyai kepentingan yang saling bertentangan (Patrick et al., 2015) . Pemikiran bahwa pihak manajemen dapat melakukan tindakan yang hanya memberikan keuntungan bagi dirinya sendiri didasarkan pada suatu asumsi yang menyatakan setiap orang mempunyai perilaku yang mementingkan diri sendiri atau self interested behaviour. Keinginan, motivasi dan utilitas yang tidak sama antara manajemen dan pemegang saham menimbulkan kemungkinan manajemen bertindak merugikan pemegang saham, antara lain 
berperilaku tidak etis dan cenderung melakukan kecurangan akuntansi dengan melakukan rekayasa laba atau earnings management guna menaikkan atau menurunkan angka akrual dalam laporan laba rugi. Jika hal ini terjadi akan mengakibatkan rendahnya kualitas laba.

Manajemen laba menjadi pusat perhatian bagi para pengguna laporan keuangan dalam menggunakannya. Manajemen laba merupakan keikutsertaan pihak manajemen dalam proses laporan keuangan perusahaan. Dengan adanya ambisi dalam memaksimalkan laba, banyak perusahaan yang mempercantik pelaporan laba yang akan dilaporkan. Tindakan mempercantik terhadap laba sering dikenal dengan istilah manajemen laba. Hal ini memungkinkan terjadinya dua hal yaitu, kemungkinan terjadinya penurunan laba atau kenaikan laba dengan cara manipulasi (Pasaribu et al., 2015).

Manajemen laba merupakan suatu bentuk intervensi dengan tujuan tertentu dalam proses penyusunan laporan keuangan untuk memperoleh beberapa keuntungan pribadi dan tentu saja dengan memperhatikan atau tetap berpedoman pada standar akuntansi yang ada. Manajemen laba dalam suatu perusahaan sangat erat kaitannya dengan tingkat kualitas dari laba yang akan dilaporkan atau yang dikenal dengan istilah earnings quality. Biasanya kualitas laba yang tinggi akan dipandang baik oleh pengguna laporan keuangan sehingga sebagian besar perusahaan melakukan tindakan manajemen laba. Menurut Algharaballi (2013), sistem pelaporan keuangan dapat dilakukan oleh manajemen perusahaan secara bebas untuk memilih metode akuntansi dan pelaporan yang tersedia. Hal ini menyebabkan kasus manajemen dapat memilih metode pelaporan serta metode akuntansi yang dapat menyesatkan pengguna informasi tersebut.

Beberapa penelitian sebelumnya telah mengkaji masalah manajemen laba yang dikaitkan dengan kualitas laba (earning quality). Menurut hasil penelitian Suardi (2017) menyatakan bahwa manajemen laba berpengaruh negatif dan signifikan terhadap kualitas laba. Namun Nuryani (2010) menyatakan bahwa manajemen laba berpengaruh positif signifikan terhadap kualitas laba. Hal ini sejalan dengan penelitian Boediono (2005), meneliti tentang pengaruh earning management terhadap earnings quality. Hasil penelitiannya menunjukkan hubungan positif antara manajemen laba terhadap earnings quality yaitu sebesar 2,56 persen, dan ini berarti kinerja manajemen dapat secara langsung dilihat dari praktik manajemen laba yang dilakukannya.

Likuiditas perusahaan menunjukkan kemampuan perusahaan dalam membayar utang jangka pendeknya yang jatuh tempo. Likuiditas akan diukur dengan menggunakan current ratio. Current ratio merupakan indikator terbaik sampai sejauh mana klaim dari kreditur jangka pendek telah ditutup oleh aktivaaktiva yang diharapkan dapat diubah menjadi kas dengan cukup cepat (Brigham \& Houston, 2013). Current ratio yang tinggi biasanya dianggap menunjukkan tidak terjadi masalah dalam likuiditas. Perusahaan dengan likuiditas tinggi akan memiliki risiko yang relatif kecil sehingga kreditur merasa yakin dalam memberikan pinjaman kepada perusahaan dan investor akan tertarik untuk menginvestasikan dananya ke perusahaan tersebut karena investor yakin bahwa perusahaan mampu bertahan (tidak likuidasi). Likuiditas perusahaan ditunjukkan 
oleh besar kecilnya aktiva lancar yaitu aktiva yang mudah untuk diubah menjadi kas. Aktiva lancar meliputi kas surat berharga, piutang, persediaan.

Perusahaan yang memiliki rasio lancar yang semakin besar, maka menunjukkan semakin besar kemampuan perusahaan untuk memenuhi kewajiban jangka pendeknya. Hal ini menunjukkan perusahaan melakukan penempatan dana yang besar pada sisi aktiva lancar. Penempatan dana yang terlalu besar pada sisi aktiva memiliki dua efek yang sangat berlainan. Di satu sisi, likuiditas perusahaan semakin baik. Namun di sisi lain, perusahaan kehilangan kesempatan untuk mendapatkan tambahan laba, karena dana yang seharusnya digunakan untuk investasi yang menguntungkan perusahaan, dicadangkan untuk memenuhi likuiditas (Jaya \& Wirama, 2017). Semakin besar rasio ini, semakin besar likuiditas perusahaan. Likuiditas perusahaan berbanding terbaik dengan profitabilitas, maksudnya semakin likuiditas perusahaan maka kemampuan perusahaan untuk menghasilkan laba semakin rendah. Kemampuan perusahaan yang semakin rendah memperoleh laba, mengindikasikan perusahaan akan lebih cenderung melakukan manipulasi laba untuk menarik minat investor dalam berinvestasi, sehingga laba yang dihasilkan akan semakin rendah kualitasnya.

Penelitian yang dilakukan oleh Wulansari (2013) menunjukkan bahwa likuiditas berpengaruh positif dan signifikan terhadap kualitas laba. Hasil penelitian Warianto (2013) pada hasil penelitiannya menunjukkan bahwa likuiditas berpengaruh positif signifikan terhadap kualitas laba. Sedangkan menurut Gharezi \& Zadeh (2013) menyatakan bahwa likuiditas memiliki hubungan yang lemah dan negatif pada kualitas laba. Selain itu, menurut penelitian yang dilakukan oleh Setiawan (2017) menunjukkan hasil bahwa likuiditas berpengaruh negatif dan signifikan terhadap kualitas laba, begitu juga hasil penelitian Ananda \& Ningsih (2016) yang menyatakan likuiditas berpengaruh negatif terhadap kualitas laba. Sedangkan hasil penelitian Dira \& Astika (2014) menunjukkan bahwa likuiditas tidak berpengaruh terhadap kualitas laba tetapi memiliki arah yang negatif pada perusahaan manufaktur yang terdaftar di BEI.

Temuan-temuan penelitian yang telah didiskusikan menunjukkan adanya inkonsistensi pengaruh earning management dan likuiditas Pada Kualitas Laba. Menurut Govindarajan (2014), diperlukan upaya untuk merekonsiliasi ketidakkonsistenan dengan cara mengidentifikasi faktor-faktor kondisional antara kedua variabel tersebut dengan pendekatan kontijensi. Pendekatan kontijensi muncul dari asumsi dasar pendekatan pandangan umum yang menyatakan bahwa suatu pengendalian bisa diterapkan dalam karakteristik perusahaan apapun dan dalam kondisi lingkungan dimana saja. Berdasarkan teori kontijensi maka ada dugaan bahwa terdapat faktor situasional lainnya yang mungkin akan saling berinteraksi di dalam mempengaruhi situasi tertentu. Hasil penelitian sebelumnya menunjukkan bahwa ada ketidakkonsistenan hasil antara satu peneliti dengan peneliti lainnya, sehingga disimpulkan terdapat variabel lain yang mempengaruhinya. Tujuan penggunaan pendekatan kontijensi adalah untuk mengindentifikasi berbagai variabel kontijensi yang mempengaruhi kualitas laba. Penggunaan pendekatan kontijensi tersebut memungkinkan adanya variabelvariabel lain yang bertindak sebagai variabel moderating atau variabel intervening. Dengan demikian, melalui pendekatan kontijensi penelitian ini mengargumenkan 
manajemen laba, kualitas laba pada kualitas laba dipengaruhi oleh good corporate governance.

Beberapa kasus skandal akuntansi yang terjadi di Indonesia tersebut mencerminkan bahwa masih adanya kesempatan bagi pihak manajer untuk memanipulasi laporan keuangannya. Kasus skandal pelaporan keuangan yang telah terjadi tersebut menimbulkan pertanyaan bagaimana efektivitas penerapan good corporate governance (GCG) dalam sebuah perusahaan untuk mencegah terjadinya praktik manajemen laba. Kemungkinan perilaku oportunistik ini meningkat dengan adanya penerapan GCG yang lemah, yang akhirnya menyebabkan kualitas laba yang dilaporkan tidak sesuai dan mengurangi kepercayaan investor terhadap laporan keuangan (González \& García-Meca, 2014).

Menurut Organization of Economic Cooperation and Development (OECD, 2015) tujuan dari good corporate governance adalah untuk membantu perusahaan membangun kepercayaan, transparansi dan akuntabilitas yang diperlukan untuk mengembangkan investasi jangka panjang, stabilitas keuangan dan integritas bisnis, dengan mendukung pertumbuhan yang lebih kuat dan masyarakat yang lebih inklusif. Good corporate governance melibatkan serangkaian hubungan antara manajemen perusahaan, dewan direksi, stakeholder, dan pemangku kepentingan lainnya. Good corporate governance memiliki struktur yang menjelaskan bagaimana aturan dan prosedur dalam pengambilan dan keputusan suatu kebijakan sehingga tujuan perusahaan dan pemantaun kinerjanya dapat dipertanggungjawabkan. Implementasi corporate governance yang baik oleh perusahaan berguna untuk mencegah terjadi tindakan manajemen laba, karena tata kelola perusahaan bertujuan untuk memberikan laporan keuangan secara tepat waktu serta memberikan pengawasan dalam membuat laporan keuangan (Veronica \& Bachtiar, 2005).

Konflik kepentingan terjadi antara pemilik perusahaan dengan manajemen dapat diminimalkan dengan suatu mekanisme monitoring yang mampu menyeimbangkan kepentingan antara pihak manajemen dan pemegang saham maupun pihak lainnya. Oleh sebab itu, emiten diharapkan dapat mempertimbangkan penerapan good corporate governance. Corporate governance adalah konsep yang didasarkan pada teori keagenan, corporate governance diharapkan berfungsi sebagai alat untuk memberikan jaminan kepada investor bahwa mereka akan menerima pengembalian dana yang telah mereka investasikan (Yuniarti et al., 2017). Secara konkret penggunaan Corporate Governance memiliki beberapa tujuan yaitu memberikan kemudahan informasi mengenai akses investasi domestik maupun asing, mendapatkan cost of capital yang lebih murah, memberikan sebuah keputusan terhadap kinerja ekonomi perusahaan, dapat meningkatkan kepercayaan stakeholders terhadap perusahaan (Almadara, 2017). Oleh karena itu, implikasi yang timbul dari adanya GCG yang kuat disuatu perusahaan diduga akan mempengaruhi hubungan manajemen laba, likuiditas dan kualitas laba. Peneliti berusaha untuk mengkaji ulang atas permasalahan di atas dengan periodisasi dan objek penelitian yang lebih update serta penggunaan variabel-variabel yang lebih kompleks.

Corporate Governance adalah konsep yang didasarkan pada teori keagenan, corporate governance diharapkan berfungsi sebagai alat untuk memberikan jaminan 
kepada investor bahwa mereka akan menerima pengembalian dana yang telah mereka investasikan (Yuniarti et al., 2017). Jensen \& Meckling (1976) menjelaskan dalam masalah keagenan, para manajer tidak selalu bertindak sesuai dengan kepentingan yang diinginkan oleh investor, maka dari itu diperlukannya pengawasan terhadap manajer namun, sulit untuk memastikan manajer melakukan keputusan yang optimal sesuai dengan kepentingan investor, manajer juga mempunyai kesempatan menggunakan profit perusahaan untuk menguntungkan dirinya sendiri.

Tjondro \& Wilopo (2011) menyatakan penerapan good corporate governance mampu memberikan perlindungan yang efektif terhadap stakeholder dan shareholder, maka para pemangku kepentingan dapat percaya atas kembalinya investasi yang mereka tanam kan. Lemahnya corporate governance merupakan salah satu penyebab krisis keuangan di Indonesia, sekaligus mengindikasikan kegagalan laporan keuangan mencapai tujuannya dalam menyampaikan fakta riil mengenai kondisi ekonomi perusahaan yang sesungguhnya terutama informasi terhadap laba kepada para penggunanya. Good corporate governance merupakan salah satu upaya yang dapat dilakukan dalam rangka meningkatkan nilai perusahaan sekaligus mencegah terjadinya manajemen laba yang dilakukan perusahaan, yang pada gilirannya akan mampu meningkatkan kepercayaan investor atas laporan keuangan perusahaan tersebut.

Upaya peningkatan Good Corporate Governance di Indonesia, telah dilakukan dengan penilaian indeks tata kelola perusahaan setiap tahunnya. Perusahaan yang mengikuti ajang ini akan masuk dalam Corporate Governance Perception Index (CGPI). Mengacu pada nilai CGPI, para pemegang saham berharap semakin baiknya corporate governance perusahaan akan membuat kinerja perusahaan semakin baik. Kinerja perusahaan yang semakin baik diharapkan mampu meminimalisir praktik manajemen laba sehingga laporan keuangan yang dihasilkan lebih dapat menggambarkan kondisi perusahaan yang sebenarnya (Yudiastuti \& Wirasedana, 2018). Dengan adanya tata kelola perusahaan yang baik, diharapkan kualitas laporan keuangan akan dinilai dengan baik oleh investor.

Penelitian yang dilakukan oleh Sulaeman (2017) menunjukkan bahwa manajemen laba berpengaruh negatif terhadap kualitas laba, hal ini didukung oleh penelitian Farichah (2017), Ahmadpour \& Shahsavari (2016) yang menyatakan manajemen laba berpengaruh negatif pada kualitas laba. Sedangkan penelitian yang dilakukan oleh Lestari \& Cahyati (2017) menunjukkan hasil bahwa GCG berpengaruh positif terhadap kualitas laba, hal ini sejalan dengan penelitian Nadirsyah (2015) yang menyatakan struktur modal dan GCG berpengaruh positif terhadap kualitas laba. Oleh karena itu, implikasi yang timbul dari adanya GCG yang kuat disuatu perusahaan diduga akan mempengaruhi hubungan manajemen laba dan kualitas laba. Berdasarkan uraian tersebut, maka hipotesis yang dapat dikembangkan adalah sebagai berikut.

$\mathrm{H}_{1}$ : Semakin tinggi earnings management maka kualitas laba semakin rendah terutama perusahaan yang memiliki good corporate governance yang lemah.

Likuiditas perusahaan menunjukkan kemampuan perusahaan dalam membayar utang jangka pendeknya yang jatuh tempo. Perusahaan dengan likuiditas tinggi akan memiliki risiko yang relatif kecil. Kreditur merasa yakin 
dalam memberikan pinjaman kepada perusahaan dan investor akan tertarik untuk menginvestasikan dananya ke perusahaan tersebut. Perusahaan yang memiliki tingkat likuiditas/rasio lancar yang semakin besar, maka menunjukkan semakin besar kemampuan perusahaan untuk memenuhi kewajiban jangka pendeknya. Hal ini menunjukkan perusahaan melakukan penempatan dana yang besar pada sisi aktiva lancar. Penempatan dana yang terlalu besar pada sisi aktiva memiliki dua efek yang sangat berlainan. Di satu sisi, likuiditas perusahaan semakin baik, namun di sisi lain, perusahaan kehilangan kesempatan untuk mendapatkan tambahan laba, karena dana yang seharusnya digunakan untuk investasi yang menguntungkan perusahaan, dicadangkan untuk memenuhi likuiditas. Hal tersebut dapat menurunkan kinerja keuangan karena ada indikasi untuk memanipulasi informasi laba atau melakukan praktik manajemen laba. Hal tersebut dapat merusak kepercayaan investor dan mengurangi kredibilitas perusahaan karena mereka menilai kualitas laba yang dihasilkan tidak sesuai dengan kenyataan yang ada (Nugroho \& Radyasa, 2020).

Tata kelola perusahaan merupakan suatu sistem atau proses yang dipakai untuk menstimulasi, akuntabilitas dan keberhasilan usaha. GCG dapat mendorong terciptanya pangsa pasar yang transparan dan efisien karena para investor biasanya percaya untuk berinvestasi ke perusahaan yang memiliki tata kelola yang baik. Dengan adanya tata kelola yang baik maka dapat mengontrol para manajer dalam melakukan dan menjalankan operasional perusahaan. Sehingga dengan adanya tata kelola yang baik dinilai dapat mengontrol tingkat likuiditas yang terlalu tinggi di suatu perusahaan, sehingga perusahaan dinilai dapat mengelola aktiva lancarnya secara maksimal, sehingga berdampak kepada kualitas laba yang dihasilkan dapat lebih dipercaya (Komite Nasional Kebijakan Governance, 2006) dan (Setyawan \& Putri, 2013).

Hasil penelitian yang dilakukan oleh Saraswati (2020) menunjukkan bahwa likuiditas berpengaruh positif pada kualitas laba, hal ini di dukung pula oleh penelitian dari Silfi (2016) dan Wulansari (2013) yang menunjukkan hasil positif pengaruh likuiditas pada kualitas laba. Berkaitan dengan GCG, penelitian Suryati (2020) menunjukkan bahwa good corporate governance berpengaruh positif dan signifikan terhadap kualitas laba, hal ini sejalan dengan penelitian Wati (2017) yang menunjukkan pengaruh yang positif GCG pada kualitas laba. Oleh karena itu, adanya unsur good corporate governance dikatakan dapat mempengaruhi hubungan likuiditas perusahaan pada kualitas laba. Berdasarkan uraian tersebut, maka hipotesis yang dapat dikembangkan adalah sebagai berikut.

$\mathrm{H}_{2}$ : Semakin tinggi tingkat likuiditas maka kualitas laba semakin tinggi terutama perusahaan yang memiliki good corporate governance yang kuat.

\section{METODE PENELITIAN}

Dalam penelitian ini pendekatan yang digunakan yaitu pendekatan kuantitatif (positivism) yang berbentuk asosiatif (hubungan sebab akibat), dengan tujuan untuk mengetahui pengaruh variabel independen yaitu earnings management, likuiditas pada variabel dependen yaitu kualitas laba dengan variabel moderasi yaitu good corporate governance. Perusahaan yang terdaftar di Bursa Efek Indonesia (BEI) yang termasuk dalam pemeringkatan CGPI yang dilakukan oleh lembaga Indonesian Institute for Corporate Governance (IICG) periode 2014-2018 merupakan 
tempat penelitian ini dilakukan. Teknik pengambilan sampel dalam penelitian ini adalah teknik purposive sampling yaitu data dipilih berdasarkan kriteria perusahaan yang masuk dan berkomitmen dalam pemeringkatan CGPI berturutturut pada tahun 2014-2018 dan menerbitkan laporan keuangan auditan dengan menggunakan tahun buku yang berakhir pada tanggal 31 Desember secara konsisten dan dinyatakan dalam rupiah.

Variabel bebas dalam penelitian ini adalah earnings management $\left(\mathrm{X}_{1}\right)$, likuiditas $\left(\mathrm{X}_{2}\right)$. Earnings management pada penelitian ini menggunakan diskresioner akrual (DA), yang diukur melalui modified jones model. Perhitungan earnings management ini mengacu pada penelitian Dechow et al. (2012) dengan rumus sebagai berikut.

Dait $=\frac{T A \text { it }}{\mathrm{A} \text { it-1 }}-\mathrm{NDA}_{\mathrm{it}}$

Likuiditas dalam penelitian ini dihitung dengan menggunakan current ratio yaitu dengan membandingkan total aset lancar dengan hutang lancar. Perhitungan likuiditas ini mengacu pada penelitian Brigham \& Houston (2013) dengan rumus sebagai berikut.

Current Ratio $=\frac{\text { Current Assets }}{\text { Current Liabilities }}$....

Variabel terikat dalam penelitian ini adalah Kualitas Laba (Y). Perhitungan kualitas laba ini menggunakan quality of income ratio, yaitu dengan cara perbandingan cash flow from operation dan net operation income. Analisis quality of income menunjukkan varians antara arus kas dari aktivitas operasi dengan laba bersih operasi perusahaan. Perhitungan kualitas laba ini mengacu pada penelitian Prastowo \& Julianty (2008) dengan rumus sebagai berikut.

Quality of income ratio $=\frac{\text { Cash flow from operation }}{\text { Net operation income }}$

Variabel moderasi pada penelitian ini yaitu Good Corporate Governance. Skor CGPI perusahaan menjadi tolak ukur perhitungan GCG dalam penelitian ini. Laporan yang dilakukan oleh IICG dapat memberikan gambaran secara langsung mengenai penerapan GCG didalam perusahaan sehingga menjadi alasan digunakannya Corporate Governance Perception Index ini. Rentang nilai yang diperoleh yaitu dari sangat terpercaya ke cukup terpercaya. Metode penentuan sampel yang diterapkan pada penelitian ini yaitu metode purposive sampling. Metode dokumentasi merupakan metode yang digunakan dalam memperoleh/mengumpulkan data pada penelitian ini. Selain itu, digunakan moderated regression analysis dalam teknik analisis data, dengan persamaan.

$Y=\alpha+\beta_{1} X_{1}+\beta_{2} X_{2}+\beta_{3} X_{3}+\beta_{4}\left(X_{1}^{*} Z\right)+\beta_{5}\left(X_{2}^{*} Z\right)+\varepsilon$

Keterangan:

Y = Kualitas Laba

$\mathrm{a} \quad=$ Konstanta

$\mathrm{X}_{1} \quad=$ Earnings Management

$\mathrm{X}_{2} \quad=$ Likuiditas

$\mathrm{X}_{3} \quad=$ Good Corporate Governance

$\mathrm{X}_{1} \mathrm{X}_{3} \quad=$ Interaksi antara earnings management dan good corporate governance.

$\mathrm{X}_{2} \mathrm{X}_{3}=$ Interaksi antara likuiditas dan good corporate governance.

$\beta_{1} \beta_{3}=$ Koefisien regresi

$\varepsilon=$ error term 


\section{HASIL DAN PEMBAHASAN}

Penelitian ini menggunakan sampel perusahaan yang terdaftar di BEI serta masuk dalam pemeringkatan CGPI secara berturut-turut periode tahun 2014-2018. Berdasarkan hasil seleksi dengan metode purposive sampling maka diperoleh jumlah perusahaan yang menjadi sampel yaitu 7 perusahaan. Jadi jumlah pengamatannya adalah 36 observasi. Deskripsi variabel penelitian menyampaikan informasi terkait karakteristik variabel-variabel penelitian yang meliputi total pengamatan, nilai maksimum, nilai minimum, nilai rata-rata (mean) dan standar deviasi. Hasil statistik deskriptif dapat dilihat pada Tabel 1.

Tabel 1. Hasil Uji Statistik Deskriptif

\begin{tabular}{lccccc}
\hline Variabel & $\mathrm{N}$ & Minimum & Maximum & Mean & Std. Deviation \\
\hline Earnings Management & 35 & $-0,244$ & 0,118 & $-0,013$ & 0,069 \\
Likuiditas & 35 & 0,222 & 2,463 & 1,204 & 0,468 \\
GCG & 35 & 69,720 & 94,860 & 86,256 & 6,271 \\
Kualitas laba & 35 & $-1,836$ & 6,082 & 1,166 & 1,763 \\
Valid N (listwise) & 35 & & & & \\
\hline
\end{tabular}

Sumber: Data Penelitian, 2021

Tabel 1, menunjukkan gambaran data berupa mean, maximum, minimum, dan standard deviation dari variabel yang digunakan dalam penelitian ini. Adapun variabel dalam penelitian ini terdari dari variabel dependen yaitu kualitas laba dan variabel independen yaitu manajemen laba dan likuiditas serta variabel moderasi yaitu good corporate governance (GCG). Variabel earnings management menunjukkan bahwa rata-rata (mean) dari variabel manajemen laba yaitu sebesar -0,013. Sedangkan nilai maksimum dari Manajemen Laba adalah sebesar 0,118 yaitu PT Bakrie \& Brothers (Persero) Tbk pada tahun 2014 dan nilai minimum adalah -0,244 yaitu PT Bakrie \& Brothers (Persero) Tbk pada tahun 2016. Nilai standard deviation dari Manajemen Laba yaitu sebesar 0,069 yang memiliki makna dimana terjadi penyimpangan nilai manajemen laba pada nilai rata-ratanya sebesar 0,069. Pada variabel likuiditas memiliki mean sebesar 1,204 dan standard deviation sebesar 0,468 . Standar deviasi dari tingkat likuiditas memiliki nilai yang lebih rendah dari rata-rata tingkat likuiditas, yang menunjukkan bahwa data tersebut memberikan nilai positif atau indikasi yang baik karena standar deviasi yang mencerminkan penyimpangan data yang lebih rendah. Adapun nilai maksimum dari likuiditas adalah sebesar 2,463 yaitu PT Bukit Asam (Persero) Tbk pada tahun 2017, sedangkan nilai minimum adalah 0,222 yaitu PT Bakrie \& Brothers (Persero) Tbk pada tahun 2017.

Variabel GCG mempunyai nilai mean sebesar 86,256 dan nilai standard deviation sebesar 6,271 yang memiliki makna dimana terjadi penyimpangan nilai GCG pada nilai rata-ratanya sebesar 6,271. Sedangkan nilai maksimum dari variabel GCG adalah sebesar 94,860 yaitu PT Bank Mandiri (Persero) Tbk pada tahun 2018 dengan nilai minimum sebesar 69,720 yaitu PT Bakrie \& Brothers (Persero) Tbk pada tahun 2014. Kemudian variabel kualitas laba memiliki nilai mean sebesar 1,166 dengan nilai standard deviation sebesar 1,763 yang memiliki makna dimana terjadi penyimpangan nilai kualitas laba pada nilai rata-ratanya sebesar 1,763. Variabel kualitas laba mempunyai nilai maksimum sebesar 6,0823 yaitu PT Bank OCBC NISP (Persero) Tbk pada tahun 2016, sedangkan nilai 
minimumnya yaitu sebesar -1,8367 PT Bank Tabungan Negara (Persero) Tbk pada tahun 2014. Untuk memastikan bahwa hasil yang diperoleh telah memenuhi asumsi dasar dalam analisis regresi, maka dilakukan uji asumsi klasik yang terdiri dari uji normalitas, uji multikolineritas, uji autokorelasi dan uji heteroskedastisitas.

Tabel 2. Uji Normalitas

\begin{tabular}{lr}
\hline Kolmogorov-Smirnov Z & \\
\hline $\mathrm{N}$ & Unstandardized Residual \\
Kolmogorov-Smirnov Z & 0,159 \\
Exact Sig. (2-tailed) & 0,303 \\
\hline
\end{tabular}

Sumber: Data Penelitian, 2021

Pada penelitian ini Uji Kolmogorov Smirnov digunakan untuk menguji normalitas data melalui pendekatan exact $p$ value. Hasil pengujian normalitas berdasarkan Tabel 2, diperoleh nilai sig. sebesar 0,303 lebih besar dari 0,05. Dengan demikian, hasil ini menunjukkan bahwa data pada model regresi yang diterapkan dalam penelitian ini telah berdistribusi normal.

Tabel 3. Uji Multikolinearitas

\begin{tabular}{llcc}
\hline \multirow{2}{*}{ Model } & & \multicolumn{2}{c}{ Collinearity Statistics } \\
\cline { 3 - 4 } & & Tolerance & VIF \\
\hline \multirow{2}{*}{1} & Earnings Management & 0,902 & 1,109 \\
& Likuiditas & 0,667 & 1,498 \\
& Kualitas laba & 0,682 & 1,467 \\
\hline
\end{tabular}

Sumber: Data Penelitian, 2021

Uji multikolinearitas bertujuan untuk menguji apakah didalam model regresi terdapat adanya korelasi antar variabel bebas. Dapat dilihat pada Tabel 3, nilai VIF dan tolerance, dimana Tabel 3, tersebut menunjukkan bahwa tidak adanya nilai VIF yang lebih besar dari 10 dan nilai tolerance yang kurang dari 0,1. Dengan demikian, melalui nilai Tolerance dan VIF yang dihasilkan pada model analisis tersebut tidak ditemukan adanya gejala multikolinearitas.

Tabel 4. Uji Autokorelasi

\begin{tabular}{lccccc}
\hline Model & $\mathrm{R}$ & $\mathrm{R}$ Square & $\begin{array}{c}\text { Adjusted } \mathrm{R} \\
\text { Square }\end{array}$ & $\begin{array}{c}\text { Std. Error of the } \\
\text { Estimate }\end{array}$ & $\begin{array}{c}\text { Durbin- } \\
\text { Watson }\end{array}$ \\
\hline 1 & 0,109 & 0,012 & $-0,084$ & 1,835 & 2,114 \\
\hline Sumber: Data Penelitian, 2021 & & &
\end{tabular}

Uji autokorelasi pada penelitian ini dengan menggunakan Uji Durbin Watson. Uji Durbin-Watson pada Tabel 4, dapat diketahui bahwa hasil uji autokorelasi menunjukkan nilai sebesar 2,114 dengan total variabel sebanyak 3 $(\mathrm{k}=3)$ dan total pengamatan $35(\mathrm{n}=35)$. Sehingga diperoleh nilai dU sebesar 1,6528 dan nilai 4-dU sebesar 2,3472. Dikarenakan d statistic berada diantara dU dan 4dU $(1,6528<2,114<2,3472)$ maka dapat disimpulkan bahwa tidak terjadi autokorelasi.

Tabel 5. Uji Heteroskedastisitas

\begin{tabular}{lll}
\hline Variabel & Sig. & Keterangan \\
\hline Manajemen laba $\left(\mathrm{X}_{1}\right)$ & 0,843 & Bebas heteroskedastisitas \\
Likuiditas $\left(\mathrm{X}_{2}\right)$ & 0,087 & Bebas heteroskedastisitas \\
GCG $(\mathrm{Z})$ & 0,531 & Bebas heteroskedastisitas \\
\hline
\end{tabular}

Sumber: Data Penelitian, 2021 
Uji heteroskedastisitas pada penelitian ini menggunakan Uji Glejser. Tabel 5 , menunjukkan bahwa nilai signifikansi dari variabel $\mathrm{X}_{1}, \mathrm{X}_{2}$ dan $\mathrm{Z}$ masing masing sebesar 0,843,0,087, 0,531. Model regresi dalam penelitian ini telah bebas dari gejala heteroskedastisitas, yang ditunjukkan pada nilai Tabel 5, yang lebih besar dari tingkat sig. 0,05. Dengan demikian, analisis moderated regression analysis dapat dilanjutkan.

\section{Tabel 6. Hasil Anaslisis Regresi Moderasi}

\begin{tabular}{|c|c|c|c|c|c|c|}
\hline \multirow{2}{*}{\multicolumn{2}{|c|}{ Model }} & \multicolumn{2}{|c|}{$\begin{array}{l}\text { Unstandardized } \\
\text { Coefficients }\end{array}$} & \multirow{2}{*}{$\begin{array}{l}\text { Standardized } \\
\text { Coefficients } \\
\text { Beta } \\
\end{array}$} & \multirow[t]{2}{*}{$\mathrm{t}$} & \multirow[t]{2}{*}{ Sig. } \\
\hline & & $\mathrm{B}$ & Std. Error & & & \\
\hline \multirow{6}{*}{1} & (Constant) & 6,680 & 7,570 & & 0,882 & 0,385 \\
\hline & $\begin{array}{l}\text { Earnings } \\
\text { Management }\end{array}$ & 210,509 & 33,017 & 8,249 & 6,376 & 0,000 \\
\hline & Likuiditas & $-2,601$ & 9,387 & $-0,691$ & $-0,277$ & 0,784 \\
\hline & GCG & $-0,068$ & 0,095 & $-0,240$ & $-0,709$ & 0,484 \\
\hline & $X_{1} Z$ & $-2,726$ & 0,421 & $-8,349$ & $-6,468$ & 0,000 \\
\hline & $\mathrm{X}_{2} \mathrm{Z}$ & 0,032 & 0,113 & 0,770 & 0,288 & 0,775 \\
\hline \multicolumn{2}{|c|}{ R Square } & 0,598 & & & & \\
\hline \multicolumn{2}{|c|}{ Adjusted R Square } & 0,528 & & & & \\
\hline \multicolumn{2}{|c|}{ F Statistik } & 8,613 & & & & \\
\hline \multicolumn{2}{|c|}{ Signifikansi Uji F } & 0,000 & & & & \\
\hline
\end{tabular}

Dari hasil analisis regresi, maka model persamaan regresi yang dikembangkan dalam penelitian ini adalah sebagai berikut.

$$
Y=6,680+210,509 X_{1}-2,601 X_{2}-0,068 Z-2,726\left(X_{1}^{*} Z\right)+0,032\left(X_{2}^{*} Z\right)
$$

Dari hasil model persamaan regresi menunjukkan bahwa, nilai konstanta sebesar 6,680, artinya nilai kualitas laba sebesar 6,680 satu satuan, apabila manajemen laba, likuiditas dan good corporate governance bernilai nol satuan. Koefisien regresi Manajemen Laba, sebesar 210,509 membuktikan bahwa setiap kenaikan satu satuan manajemen laba akan menaikkan 210,509 satu satuan pada kualitas laba. Koefisien regresi Likuiditas, sebesar -2,601 menunjukkan bahwa setiap kenaikan satu satuan likuiditas maka akan menurunkan 2,601 satu satuan pada kualitas laba. Koefisien regresi GCG, sebesar -0,068 menunjukkan bahwa setiap kenaikan satu satuan good corporate governance mana akan menurunkan 0,068 satu satuan pada kualitas laba. Koefisien regresi moderasi $X_{1} Z$ sebesar -2,726, menunjukkan bahwa variabel moderasi melemahkan pengaruh manajemen laba terhadap kualitas laba. Tingkat signifikansi yang diperoleh dari moderasi $\mathrm{X}_{1}$ dan $Z$ yaitu sebesar 0,000 . Suatu model regresi dapat dikatakan memoderasi pengaruh variabel independen terhadap dependen nya apabila nilai signifikansi $<0,05$. Dapat disimpulkan bahwa model regresi tersebut mampu memoderasi variabel dependen karena tingkat signifikansi sebesar 0,000 atau $<0,05$. Koefisien regresi moderasi X2Z sebesar 0,032, menunjukkan bahwa variabel moderasi memperkuat hubungan likuiditas terhadap kualitas laba. Tingkat signifikansi yang diperoleh dari moderasi $\mathrm{X} 2$ dan $\mathrm{Z}$ yaitu sebesar 0,775. Suatu model regresi dikatakan memoderasi pengaruh variabel independen terhadap dependen nya apabila nilai signifikansi $<0,05$. Dapat disimpulkan bahwa moderasi GCG dengan likuiditas tidak ada pengaruh karena tingkat signifikansi sebesar 0,775 atau >0,05. 
Pada Tabel 6, dapat dilihat bahwa nilai $\mathrm{F}$ hitung sebesar 8,613 dan nilai signifikansi $\mathrm{F}$ atau $p$-value sebesar 0,000 yang lebih kecil dari $a=0,05$. Hal ini berarti model analisis layak untuk digunakan. Tabel 6, juga memberikan gambaran mengenai nilai Adjusted $\mathrm{R}^{2}$ penelitian ini sebesar 0,528 yang berarti 52,8 persen variansi dari variabel dependen, yaitu Kualitas Laba dapat dijelaskan oleh variansi variabel manajemen laba, likuiditas serta moderasi good corporate governance sedangkan sisanya 47,2 persen diterangkan oleh faktor lain yang tidak diikutkan ke dalam model.

Hasil penelitian menyatakan bahwa GCG memoderasi (memperlemah) hubungan pengaruh manajemen laba terhadap kualitas laba perusahaan. Koefisien negatif tersebut kemungkinan disebabkan karena banyak tujuan manajer untuk melakukan manajemen laba seperti mendapatkan bonus dan penghematan pajak, hal tersebut yang menjadi tujuan utama manajer dalam melakukan manajemen laba jika dibandingkan dengan tujuan meningkatkan kualitas laba. Disamping itu, good corporate governance merupakan konsep yang didasarkan pada teori keagenan. Teori keagenan menjelaskan latar belakang terjadinya manajemen laba di perusahaan. Menurut Jensen \& Meckling (1976) teori keagenan menjelaskan mengenai sebuah kontrak antara manajer (agen) dengan pemilik perusahaan (prinsipal). Diantara prinsipal dan agen, investor lebih menginginkan laporan dari pihak agen karena agen yang mengelola manajemen perusahaan sehingga lebih mengetahui mengenai kondisi perusahaan yang sesungguhnya, sedangkan prinsipal hanya sebagai pemilik perusahaan yang menerima laporan dari pihak manajemen. Ketidakseimbangan informasi yang dimiliki oleh prinsipal dan agen mengenai kondisi perusahaan disebut asimetri informasi. Asimetri informasi yang terjadi antara prinsipal dan agen menyebabkan terjadinya konflik kepentingan. Konflik kepentingan dapat mendorong pihak agen untuk melakukan penyimpangan dalam menyajikan informasi kepada pemilik perusahaan. Penyimpangan yang terjadi adalah manajemen mempengaruhi tingkat laba dalam laporan keuangan atau sering disebut manajemen laba. Untuk mengendalikan tindakan pihak agen tersebut, maka corporate governance merupakan suatu mekanisme monitoring yang tepat digunakan oleh pemegang saham dan kreditor perusahaan maupun pihak berkepentingan lainnya untuk mengurangi konflik kepentingan/konflik keagenan dan juga menekan tindakan manajemen untuk berperilaku oportunistik di dalam suatu perusahaan.

Hal ini menunjukkan bahwa perusahaan-perusahaan dengan tata kelola yang baik atau perusahaan yang termasuk dalam pemeringkatan Corporate Governance Perception Index (CGPI) berpengaruh signifikan dalam mengurangi/menekan tindakan manajemen laba yang dilakukan pihak manajemen/agen dengan alasan bahwa tata kelola perusahaan yang baik tersebut mampu mencegah tindakan oportunistik manajemen di dalam suatu perusahaan tersebut, sehingga hal tersebut dapat meningkatkan kepercayaan investor maupun pihak-pihak yang berkepentingan lainnya terhadap laporan keuangan yang diterbitkan perusahaan. Dengan demikian, hal tersebut juga akan meningkatkan tingkat kualitas laba perusahaan. Hasil penelitian ini sejalan dengan penelitian yang dilakukan oleh Rifani (2013) yang menyatakan GCG yang diproksikan dengan indeks CGPI memperlemah pengaruh hubungan manajemen 
laba terhadap kualitas laba perusahaan. Penelitian Rifani didukung oleh penelitian yang dilakukan oleh Suardi (2017) yang menyatakan bahwa good corporate governance memperlemah pengaruh manajemen laba terhadap kualitas laba.

Hasil penelitian menunjukkan bahwa perusahaan-perusahaan yang termasuk dalam pemeringkatan Corporate Governance Perception Index (CGPI) tidak memiliki pengaruh terhadap likuiditas perusahaan maupun pengaruhnya terhadap kualitas laba suatu perusahaan. GCG tidak mampu memperlemah maupun memperkuat pengaruh likuiditas terhadap kualitas laba. GCG dalam penelitian ini diproksikan dengan Corporate Governance Perception Index (CGPI) yang berarti proksi tersebut belum mampu memberikan batasan atau kontrol kepada pihak manajemen dalam melakukan aktivitasnya di dalam suatu perusahaan. Hal ini mungkin dikarenakan kualitas laba dilihat dari pergerakan arus kas operasi, sedangkan likuiditas diambil berdasarkan ending balance dari saldo current asset dan current liabilities, sehingga jika likuiditas perusahaan tinggi belum tentu kualitas laba perusahaannya juga semakin baik. Hal ini juga dikarenakan apabila likuiditas perusahaan terlalu besar maka perusahaan tersebut tidak mampu mengelola aktiva lancarnya semaksimal mungkin sehingga kinerja keuangan menjadi kurang baik dan kemungkinan ada manipulasi laba untuk mempercantik informasi laba tersebut.

Oleh karena itu, investor mungkin merespon negatif terhadap tingginya tingkat likuiditas suatu perusahaan. Hasil dari penelitian ini sejalan dengan penelitian Dira \& Astika (2014), Nugroho \& Radyasa (2020), bahwa likuiditas tidak berpengaruh terhadap kualitas laba. Hal ini berarti dengan semakin baiknya kemampuan perusahaan dalam memenuhi hutang dan kewajibannya, tidak menjadi jaminan bahwa kualitas laba dari perusahaan tersebut juga dalam keadaan baik.

\section{SIMPULAN}

Berdasarkan hasil pengujian dan pembahasan yang telah diuraikan, maka simpulan yang diperoleh sebagai berikut. Good corporate governance berpengaruh signifikan negatif terhadap hubungan manajemen laba dan kualitas laba. Tindakan manajemen laba yang bersifat merugikan yang dilakukan oleh agen dalam suatu perusahaan dapat dikurangi/diperlemah dengan semakin tingginya tingkat good corporate governance yang terdapat pada perusahaan dan pada akhirnya dapat meningkatkan tingkat kualitas laba pada perusahaan. Kemudian, good corporate governance tidak memiliki pengaruh/tidak dapat memoderasi pengaruh likuiditas terhadap kualitas laba. Moderasi GCG pada likuiditas terhadap kualitas laba ini memiliki arah yang positif namun tidak signifikan (tidak berpengaruh). Hal ini berarti pemenuhan kewajiban/hutang perusahaan oleh perusahaan yang semakin baik, bukan tolak ukur bahwa kualitas laba yang dimiliki perusahaan dalam keadaan baik.

Hasil penelitian ini tentunya dapat dijadikan bahan pertimbangan bagi peneliti selanjutnya, di mana peneliti menyarankan agar memperpanjang atau menambahkan periode penelitian serta menambah perusahaan-perusahaan lainnya yang tidak hanya termasuk dalam pemeringkatan CGPI atau menggunakan proksi selain skor penilaian CGPI didalam metode penilaian Good 
Corporate Governance, dikarenakan keterbatasan jumlah sampel penelitian yang didapat. Kemudian, hendaknya menggunakan variabel independen lainnya yang berpengaruh terhadap kualitas laba perusahaan, diantaranya asimetri informasi, investment opportunity set dan leverage. Selain itu, tentunya diharapkan agar perusahaan lebih pastisipatif dan komitmen dalam mengikuti/menerapkan konsep good corporate governance (GCG) yang diadakan oleh lembaga The Indonesian Institute of Corporate Governance (IICG).

\section{REFERENSI}

Ahmadpour, A., \& Shahsavari, M. (2016). Earnings Management and the Effect of Earnings Quality in Relation to Bankruptcy Level (Firms Listed at the Tehran Stock Exchange). Iranian Journal of Management Studies, 9(1), 77-99. https://doi.org/10.22059/ijms.2016.55036

Algharaballi, E. (2013). Earnings Management Practices and Subsequent Firm Performance of Companies Listing on The Kuwait Stock Exchange (KSE). Thesis, 19(2), 215-231.

Almadara, H. U. (2017). Pengaruh Leverage Terhadap Manajemen Laba dengan Corporate Governance Sebagai Variabel Pada Perusahaan Perbankan yang Terdaftar di BEI. Jurnal Ekonomi Universitas Negeri Yogyakarta, 3(1), 237-245.

Ananda, R., \& Ningsih, E. S. (2016). Pengaruh Likuiditas, Kepemilikan Institusional, Dan Ukuran Perusahaan Terhadap Kualitas Laba (Pada Perusahaan manufaktur Yang Terdaftar Di Bursa Efek Indonesia Tahun 20102014). Jurnal Ilmiah Mahasiswa Ekonomi Akuntansi (JIMEKA), 1(2), 277-294.

Boediono, G. S. (2005). Kualitas Laba: Studi Pengaruh Mekanisme Corporate Governance dan Dampak Manajemen Laba dengan Menggunakan Analisis Jalur. SNA VIII Solo, September, 15-16.

Brigham, E. F., \& Houston, J. F. (2013). Fundamental of Financial Management: Dasar-Dasar Manajemen Keuangan. In Jakarta: Salemba Empat. https://doi.org/10.1145/2505515.2507827

Cornett, M. M., Marcus, A. J., Saunders, A., \& Tehranian, H. (2006). Earnings Management, Corporate Governance, and True Financial Performance. SSRN Electronic Journal, 618. https://doi.org/10.2139/ssrn.886142

Dechow, P. M., Hutton, A. P., Kim, J. H., \& Sloan, R. G. (2012). Detecting Earnings Management: A New Approach. Journal of Accounting Research, 50(2), 275-334. https://doi.org/10.1111/j.1475-679X.2012.00449.x

Dira, K. P., \& Astika, I. B. P. (2014). Pengaruh struktur modal, likuiditas, pertumbuhan laba, dan ukuran perusahaan pada kualitas laba. E-Jurnal Akuntansi Universitas Udayana, 7(1), 64-78.

Fama, E. F., \& Jensen, M. C. (1983). Separation of Ownership and Control. Journal of Law and Economics, 26(2), 301-325.

Farichah. (2017). Relationship of Earnings Management And Earnings Quality Before And After Ifrs Implementation In Indonesia. European Research Studies Journal, 20(4), 70-81. https:// doi.org/10.35808/ersj/875

Fauzi, M. R. (2015). Skripsi Skripsi. Pengaruh Profitabilitas, Investment Opportunity Set (IOS), Dan Good Corporate Governance (GCG) Terhadap Kualitas Laba.

Finance, D. (2010). Katarina Diduga Manipulasi Laporan Keuangan Auditan 2009 (p. Diakses 7 Oktober 2019. ( http:/ / finance.detik.com). 
Gharezi, D., \& Zadeh, M. R. A. (2013). The Relationship Between Earnings Quality and Risk of Liquidity in Tehran Stock Exchange. Institute of Interdisciplinary Business Research, 782-805.

González, J. S., \& García-Meca, E. (2014). Does Corporate Governance Influence Earnings Management in Latin American Markets? Journal of Business Ethics, 121(3), 419-440. https:/ / doi.org/10.1007/s10551-013-1700-8

Jaya, K. A. A., \& Wirama, D. G. (2017). Pengaruh Investment Opportunity Set, Likuiditas, dan Ukuran Perusahaan Pada Kualitas Laba Fakultas. E-Jurnal Akuntansi Universitas Udayana, 21, 2195-2221.

Jensen, M. C., \& Meckling, W. H. (1976). Theory of the Firm: Managerial Behavior, Agency Costs And Ownership Structure. Journal of Financial Economics, 3(4), 305-360. https:/ / doi.org/http:/ / dx.doi.org/10.1016/0304-405X(76)90026-X

Komite Nasional Kebijakan Governance. (2006). Pedoman Umum Good Corporate Governance Indonesia. Pedoman Umum Good Corporate Governance Indonesia.

Lestari, A. K. N., \& Cahyati, A. D. (2017). Pengaruh Mekanisme Good Corporate Governance Terhadap Kualitas Laba Akuntansi Pada Perusahaan Manufaktur Di Bursa Efek Indonesia. ASSETS, 7(1), 17-40.

Nadirsyah, \& Muharram, F. N. (2015). Struktur Modal, Good Corporate Governance Dan Kualitas Laba. Jurnal Dinamika Akuntansi Dan Bisnis, 2(2), 184-198. https:/ / doi.org/10.24815/jdab.v2i2.4217

Nugroho, V., \& Radyasa, Y. (2020). Pengaruh Likuiditas, Ukuran Perusahaan, dan Leverage Terhadap Kualitas Laba Pada Perusahaan Manufaktur. Jurnal Ekonomi Dan Pembangunan, 10(2), 80-91. https://doi.org/10.22373/jep.v10i2.39

Nuryani, N. (2010). Pengaruh Restatement Laporan Keuangan dan Manajemen Laba Terhadap Kualitas Laba dengan Kualitas Audit Sebagai Variabel Pemoderasi. Jurnal Akuntansi, 01, 25-37.

OECD. (2015). G20/OECD Principles of Corporate Governance. In G20/OECD Principles of Corporate Governance. OECD Publishing. https://doi.org/10.1787/9789264257443-tr

Parsaoran, D. (2009). Skandal Manipulasi Laporan Keuangan PT. Kimia Farma Tbk. (p. Diakses 7 Oktober 2019).

Pasaribu, R. B. F., Kowanda, D., Firdaus, M., \& Ummah, R. N. (2015). Mekanisme Good Corporate Governance, Ukuran Perusahaan, Struktur Kepemilikan Manajerial dan Leverage pada Manajemen Laba pada Emiten Perbankan di Bursa Efek Indonesia. JRMB Universitas Gunadarma., 10(1), 1-22.

Patrick, E. A., Paulinus, E. C., \& Nympha, A. N. (2015). The Influence of Corporate Governance on Earnings Management Practices : A Study of Some Selected Quoted Companies in Nigeria. 1(5), 482-493.

Prastowo, D., \& Julianty, R. (2008). Analisis Laporan Keuangan. In Yogyakarta: UPP STIM YKPN.

Rifani, A. (2013). Pengaruh Good Corporate Governance Terhadap Hubungan Manajemen Laba dan Kualitas Laba. Skripsi Universitas Negeri Padang.

Sadalia, I., Hrp, A. I., \& Fachrudin, K. A. (2017). The Effect of Leverage and Financial Distress on Earnings Management with Good Corporate Governance as the Moderating Variable. Academic Journal of Economic Studies, $3(4), 86-95$. 
Saraswati, K. F. D., Merawati, L. K., \& Munidewi, I. A. B. (2020). Pengaruh likuiditas, Leverage dan Good Corporate Governance Terhadap Kualitas Laba. Jurnal Riset Akuntansi Universitas Mahasaraswati, 15(2), 79-89.

Schipper, K., \& Vincent, L. (2003). Earnings Quality - Shipper 2003. Accounting Horizons, 97-110.

Setiawan, B. R. (2017). Pengaruh Ukuran Perusahaan, Profitabilitas, Likuiditas dan Leverage Terhadap Kualitas Laba Pada Perusahaan Manufaktur Industri Barang Konsumsi Yang Terdaftar di BEI. Menara Ilmu, XI(77), 36-46.

Setyawan, K. M., \& Putri, I. G. A. M. A. D. (2013). Pengaruh Good Corporate Governance Terhadap Kinerja Keuangan Lembaga Perkreditan Desa di Kecamatan Mengwi Kabupaten Badung. E-Jurnal Akuntansi Universitas Udayana, 5(3), 586-598.

Silfi, A. (2016). Pengaruh Pertumbuhan Laba, Struktur Modal, Likuiditas Dan Komite Audit Terhadap Kualitas Laba. Jurnal Valuta, 2(1), 17-26.

Suardi, M. W. A. (2017). Pengaruh Overvalued Equities Dan Earnings Management Terhadap Kualitas Laba Dengan Good Corporate Governance Sebagai Variabel Moderasi. Assets, 7(1), 86-103.

Sulaeman, E. (2017). Pengaruh Manajemen Laba Dan Komposisi Komisaris Independen Terhadap Kualitas Laba Dan Efeknya Terhadap Nilai Perusahaan. EKUITAS: Jurnal Ekonomi Dan Keuangan, 3(2), 188-205. https://doi.org/10.24034/j25485024.y2019.v3.i2.4109

Suryati, A. (2020). Pengaruh Good Corporate Governance Terhadap Kualitas Laba Dengan Ukuran Perusahaan Sebagai Variabel Moderasi. Jurnal Kajian Ilmiah (JKI), 20(3), 281-290. https:/ / doi.org/10.31599/jki.v20i3.316

Tjondro, D., \& Wilopo, R. (2011). Pengaruh Good Corporate Governance (GCG) Terhadap Profitabilitas dan Kinerja Saham Perusahaan Perbankan yang Tercatat di Bursa Efek Indonesia. Journal of Business and Banking, 1(2). https://doi.org/10.14414/jbb.v1i1.148

Veronica, S., \& Bachtiar, Y. S. (2005). The Role of Corporate Governance in Preventing Misstated Financial Statement. Jurnal Akuntansi Dan Keuangan Indonesia, 2(1), 159-173.

Warianto , P., R. C. (2013). Pengaruh Ukuran Perusahaan, Struktur Modal, Likuiditas, Investment Opportunity Set (IOS) Terhadap Kualitas Laba. Jurnal Universitas Atma Jaya. Yogyakarta.

Wati, G dan Putra, I. W. (2017). Pengaruh Ukuran Perusahaan, Leverage, Dan Good Corporate Governance pada Kualitas Laba. E-Jurnal Akuntansi Universitas Udayana, 19(1), 137-167.

Wulansari, Y. (2013). Pengaruh Investment Opportunity Set, Likuiditas dan Leverage Terhadap Kualitas Laba Pada Perusahaan MAnufaktur yang Terdaftar di BEI. Jurnal Fakultas Ekonomi Universitas Negeri Padang, 1(2).

Yudiastuti, L. N., \& Wiraseda, I. W. P. (2018). Pengaruh Leverage Terhadap Manajemen Laba. E-Jurnal Akuntansi Universitas Udayana, 23(1), 130-155.

Yuniarti, E., Mukhtaruddin, \& Hanim, N. (2017). Effect on Value Earnings Management Company with Good Corporate Governance Practices as Moderating Variable. SHS Web of Conferences, 34. https://doi.org/10.1051/ 73404007 